\title{
First Report and Morphological Description of Meloidogyne enterolobii Infecting Guava (Psidium guajava L.) in Transitional Plain of Luni Basin of Rajasthan
}

\author{
S. S. Bhati ${ }^{1 *}$ and Aabha Parashar ${ }^{2}$ \\ ${ }^{1}$ Nematology, College of Agriculture, Nagaur, Agriculture University, Jodhpur (Rajasthan) \\ India \\ ${ }^{2}$ Krishi Vigyan Kendra-Sirohi, Agriculture University, Jodhpur (Rajasthan) India \\ *Corresponding author
}

\section{A B S T R A C T}

\begin{tabular}{l} 
Ke y w o r d s \\
$\begin{array}{l}\text { First report, } \\
\text { Meloidogyne } \\
\text { enterolobii, } \\
\text { morphological } \\
\text { description, guava, } \\
\text { Sirohi }\end{array}$ \\
\hline Article Info \\
$\begin{array}{l}\text { Accepted: } \\
17 \text { August } 2020 \\
\text { Available Online: } \\
\text { 10 September } 2020\end{array}$ \\
\hline
\end{tabular}

\section{Introduction}

Guava (Psidium guajava) belongs to family myrtaceae, is one of the most important commercial fruit crop in India. It is the fourth most important fruit after mango, banana and citrus and well grown in both tropical and subtropical regions of India and gives two time fruits in a year. The fresh ripen fruit eaten raw and it is also used to make jam and superior jelly due pectin contain. Guava is a good source of antioxidants, vitamin $\mathrm{C}, \mathrm{A}$ and
Guava (Psidium guajava L.) is an important fruit crop and good source of income for Indian farmers. It's infested with some major pests including plant parasitic nematodes. The number of plant parasitic nematode species associated with guava but some species are cause great losses. The accurate identification of nematode species is a basic key of successful management. Soil and plant samples collected from fields of guava from Arathwara village, Sheoganjtehsil, Sirohi district of Rajasthan, India on the GPS location $25^{0} 03^{\prime} 40.7^{\prime \prime} \mathrm{N} ; 7^{0} 58^{\prime} 05.0^{\prime \prime} \mathrm{E}$. The nematode population was identified on the basis of morphological characters and measurements of juvenile, mature female, male and perineal pattern. The all morphological characters of specimen were similar to original description of Meloidogyne enterolobii. The population status of root-knot nematode was ranging from 934 to 1376 juveniles per $200 \mathrm{cc}$ soil. It is a first report of Meloidogyne enterolobii infested guava (Psidium guajava L.) in transitional plain of luni basin of Rajasthan. good source of antioxidants, vitamin $\mathrm{C}, \mathrm{A}$ and

$\mathrm{B}$, and different kind of minerals like calcium, iron, magnesium, phosphorus, potash etc. Therefore, it can prove to be very effective in malnutrition (Thomas et al., 2017).In India, occupying area around 2.65 lakh hectares with annual production of 40.54 lakhs MT and the export value is INR 553.26 lakhs. The most growing states are Uttar Pradesh, Madhya Pradesh, Bihar, Andhra Pradesh, TamilNadu, Rajasthan, West Bengal, Punjab, Haryana, Chhatisgarh, Gujarat etc (Anonymous, 2018-19a).In Rajasthan, it is 
cultivated mainly in Sawai Madhopur, Bundi, Bharatpur, Baran, Ajmer, Alwar, Udaipur, Chittorgarh, Bhilwara, Pali and Sirohidistricts in the area of 4621 hectares with production of 81553 MT(Anonymous, 2018-19b). These data indicates that it's very helpful crop to improve farmer's income.

The fruit crop of such an economic importance suffers from several biotic and abiotic factors. Among biotic factors, insect pests (fruit fly, weevil, scale insects, white fly, thrips etc.) and diseases (Anthracnose, leaf spot, rust etc.) are the most important ones including plant parasitic nematodes. Plant parasitic nematodes viz. Meloidogyne spp., Pratylenchus spp., Rotylenchulus reniformis, Tylenchorhynchus spp., Hoplolaimus spp., Helicotylenchus spp. and Xiphinema spp. have been found associated with different crops in Rajasthan (Bohra, 2008). Among them root-knot nematode, Meloidogyne enterolobii (Yang and Eisenback, 1983) found a serious problem in guava (Poornima et al., 2016).

The most of guava growing area of Rajasthan having sandy loam soil and it is most favorable for survival of plant parasitic nematodes mainly root-knot nematode, so the nematodes problem increase day by day in the all regions. The farmers of transitional plain of luni basin zone trying to improve their income with the help of profitable horticultural crops but the nematodes severely increase in the region and causing great losses, alone and synergistically with other pathogens. Due to availability of irrigation water, farmers grow the solanaceous and cucurbitaceous vegetables as intercrop in the orchard and these all are susceptible host of M. enterolobii (Moens et al., 2009). Among all pathogens root-knot nematode, Meloidogyne enterolobii emerge as a major pest of guava but there is no any previous report found on the presence of Meloidogyne enterolobiiin this region. Therefore, it is necessary to aware researchers about this nematode through the report.

\section{Materials and Methods}

\section{Collection of samples}

Soil and root samples collected fromArathwaravillage of Sheoganjtehsil of Sirohi district, Rajasthan on the GPS location $25^{0} 03^{\prime} 40.7^{\prime} \mathrm{N}$; 720 $58^{\prime} 05.0^{\prime}$ 'E. The guava planted on ridges and covered with the plastic mulching sheet in three different fields with three different varieties such as Barafkhana, Thai guava and Taiwan pink. The nematode infested plant of guava identified on the basis of symptoms including bronzing of leaves, less number of leaves, dead buds, yellowing, stunting and root galls (Figure-1\&2).

\section{Processing of samples}

To identification and characterization of the species, pure culture of juveniles recovered from the egg mass of root-knot nematode obtained from the guava roots, mature females recovered from the galls of guava roots and the males are recovered from both galls and soil of the infested field. To find out the population status of plant parasitic nematodes, soil samples were processed by using Cobb's Sieving and Decanting Technique (Cobb, 1918) followed by Baermann's Funnel Assembly (Christie and Perry, 1951). Roots were stained in $0.1 \%$ acid fuchsin lactophenol solution at $80^{\circ} \mathrm{C}$ for $2-3$ minutes (McBeth et al., 1941). Thereafter, soil extract and roots were examined under stereoscopic binocular microscope then mounting of nematodes and morphologically identified through binocular compound microscope. For the identification of species of root-knot nematode perineal patterns were cut (Taylor and Netscher, 1974). 


\section{Identification of nematode}

The presence of root-knot nematode identified on the basis visual root-galls formed on the root of plants. The perineal pattern and other typical morphological characters of juvenile, male and female used for identification of the common root-knot nematode species (Chitwood, 1949). In the present study, for the identification of Meloidogyne enterolobii observations taken on morphological characters of juveniles such as body length, maximum body width, stylet length and tail length. Whereas, the characters of females body length, maximum body width, neck length, stylet length and vulval length were observed during study. While, the characters of males body length, maximum body width, stylet length, tail length and spicules length were observed for confirmation of species of root-knot nematode.

\section{Results and Discussion}

\section{Morphological description of Meloidogyne enterolobii infecting guava}

The identification of Meloidogyne enterolobii was done on the basis of morphological characters during microscopic studies. The morphological characters of juvenile, mature female, perennial pattern and male are observed are coincided with original description given by (Yang and Eisenback, 1983)and described below.

\section{Juveniles of Meloidogyne enterolobii}

The juvenile having vermiform long body; head slightly set off from body; large rounded knob; hyaline tail terminus and broad tail tip. The measurements of 10 juvenile's body were recorded (Table-1). The mean body length $467.77(\mu \mathrm{m})$; maximum body width 15.21 $(\mu \mathrm{m})$; stylet length $11.93(\mu \mathrm{m})$ and tail length $53.28(\mu \mathrm{m})$ were observed and listed in table1 and illustrated in figure- 4 .

\section{Females of Meloidogyne enterolobii}

The female is pear shaped white body; tail absent; anus and vulva terminal, whereas, perineal pattern oval shaped with smooth and coarse striae; high dorsal arc; perivulval region free from striae; weak lateral lines and large size phasmids. The measurements of 10 female's body were observed as the mean body length $670.24(\mu \mathrm{m})$; maximum body width 513.52( $\mu \mathrm{m})$; neck length $311.48(\mu \mathrm{m})$; stylet length $14.89(\mu \mathrm{m})$ and vulval length $27.23(\mu \mathrm{m})$ and listed in table-2 and illustrated in figure- 3 and 4.

\section{Males of Meloidogyne enterolobii}

Male of the species is vermiform; head cap high and rounded; head slightly set off from body; stylet robust, stylet knob bold and rounded; spicules arcuate; short and rounded tail and bursa absent. The measurements of 10 male's body were observed as the mean body length $1448.15(\mu \mathrm{m})$; maximum body width 41.26( $\mu \mathrm{m})$; stylet length $22.75(\mu \mathrm{m})$; tail length $13.66(\mu \mathrm{m})$ and spicules length 28.89 $(\mu \mathrm{m})$ and listed in table- 3 and illustrated in figure-4.

\section{Population status}

Guava root and soil samples collected from GPS location $25^{0} 03^{\prime} 40.7^{\prime \prime} \mathrm{N} ; \quad 72^{0} 58^{\prime} 05.0^{\prime \prime} \mathrm{E}$. The samples collected from three different fields having three different varieties such as Barafkhana, Thai guava and Taiwan pink. These all planted in different fields on ridges and covered with plastic mulching along with drip system. Vegetables grow as an intercrop between the rows and plants. Musk melon planted in low tunnel as an intercrop in the field of Barafkhana and tomato grow in the fields of both Thai guava and Taiwan pink. Total 18 samples collected from fields and all the samples found infected with root-knot nematode, Meloidogyne enterolobii and have been shown in table-4. 
Table.1 Morphological measurement of juveniles of Meloidogyne enterolobii $(\mathrm{n}=10)$

\begin{tabular}{|l|c|c|c|c|c|}
\hline \multicolumn{1}{|c|}{ Character } & Range & Mean & $\begin{array}{c}\text { Standard } \\
\text { error of mean }\end{array}$ & $\begin{array}{c}\text { Standard } \\
\text { deviation }\end{array}$ & $\begin{array}{c}\text { Coefficient of } \\
\text { variation }(\boldsymbol{\%})\end{array}$ \\
\hline Body length $(\boldsymbol{\mu m})$ & $418.2-507.8$ & 467.77 & 10.781 & 34.092 & 7.288 \\
\hline $\begin{array}{l}\text { Maximum Body } \\
\text { width }(\boldsymbol{\mu m})\end{array}$ & $14.2-16.3$ & 15.21 & 0.221 & 0.698 & 4.591 \\
\hline Stylet length $(\boldsymbol{\mu m})$ & $11.3-12.6$ & 11.93 & 0.138 & 0.437 & 3.665 \\
\hline Tail length $(\boldsymbol{\mu m})$ & $44.6-61.7$ & 53.28 & 2.236 & 7.071 & 13.271 \\
\hline
\end{tabular}

Table.2 Morphological measurements of females of Meloidogyne enterolobii $(\mathrm{n}=10)$

\begin{tabular}{|l|c|c|c|c|c|}
\hline \multicolumn{1}{|c|}{ Character } & Range & Mean & $\begin{array}{c}\text { Standard error } \\
\text { of mean }\end{array}$ & $\begin{array}{c}\text { Standard } \\
\text { deviation }\end{array}$ & $\begin{array}{c}\text { Coefficient of } \\
\text { variation }(\boldsymbol{\%})\end{array}$ \\
\hline Body length $(\boldsymbol{\mu m})$ & $568.5-822.4$ & 670.24 & 31.012 & 98.070 & 14.632 \\
\hline $\begin{array}{l}\text { Maximum Body } \\
\text { width }(\boldsymbol{\mu m})\end{array}$ & $382.5-639.7$ & 513.52 & 27.794 & 87.891 & 17.115 \\
\hline Neck length $(\boldsymbol{\mu m})$ & $183.6-486.3$ & 311.48 & 31.529 & 99.703 & 32.010 \\
\hline Stylet length $(\boldsymbol{\mu m})$ & $12.8-17.6$ & 14.89 & 0.490 & 1.548 & 10.397 \\
\hline Vulval length $(\boldsymbol{\mu m})$ & $22.4-31.2$ & 27.23 & 1.007 & 3.186 & 11.699 \\
\hline
\end{tabular}

Table.3 Morphological measurements of males of Meloidogyne enterolobii $(\mathrm{n}=10)$

\begin{tabular}{|l|c|c|c|c|c|}
\hline \multicolumn{1}{|c|}{ Character } & Range & Mean & $\begin{array}{c}\text { Standard } \\
\text { error of mean }\end{array}$ & $\begin{array}{c}\text { Standard } \\
\text { deviation }\end{array}$ & $\begin{array}{c}\text { Coefficient of } \\
\text { variation }(\%)\end{array}$ \\
\hline Body length $(\boldsymbol{\mu m})$ & $1258.6-1634.2$ & 1448.15 & 43.432 & 137.345 & 9.484 \\
\hline $\begin{array}{l}\text { Maximum Body width } \\
(\boldsymbol{\mu m})\end{array}$ & $36.8-45.4$ & 41.26 & 1.082 & 3.422 & 8.293 \\
\hline Stylet length $(\boldsymbol{\mu m})$ & $21.0-24.8$ & 22.75 & 0.428 & 1.353 & 5.949 \\
\hline Tail length $(\boldsymbol{\mu m})$ & $10.2-16.7$ & 13.66 & 0.664 & 2.101 & 15.380 \\
\hline Spicules length $(\boldsymbol{\mu m})$ & $26.6-31.5$ & 28.89 & 0.568 & 1.797 & 6.221 \\
\hline
\end{tabular}

Table.4 Details of surveyed guava fields in Sirohi district of Rajasthan

\begin{tabular}{|c|c|c|c|c|c|}
\hline Location & Varieties & $\begin{array}{l}\text { Cropping } \\
\text { System }\end{array}$ & Intercrop & $\begin{array}{c}\text { No. of } \\
\text { samples } \\
\text { collected }\end{array}$ & $\begin{array}{c}\text { No. of samples } \\
\text { infested by } \\
\text { Nematodes }\end{array}$ \\
\hline \multirow{3}{*}{$\begin{array}{l}25^{0} 03^{\prime} 40.7^{\prime \prime} \mathrm{N} \\
7^{0} 58^{0} 05.0^{\prime \prime} \mathrm{E}\end{array}$} & BarafKhana & \multirow{4}{*}{$\begin{array}{l}\text { Plastic } \\
\text { Mulching With } \\
\text { Drip Irrigation } \\
\text { and inter } \\
\text { cropping of } \\
\text { vegetables }\end{array}$} & Musk Melon & 06 & 06 \\
\hline & Thai guava & & Tomato & 06 & 06 \\
\hline & \multirow[t]{2}{*}{ Taiwan pink } & & Tomato & 06 & 06 \\
\hline $\begin{array}{l}\text { Village: Arathwara } \\
\text { Tehsil: Sheoganj } \\
\text { District: Sirohi } \\
\text { Rajasthan, India }\end{array}$ & & & Total & 18 & 18 \\
\hline
\end{tabular}


Table.5 Population status of Meloidogyne enterolobii on different verities of Guava

\begin{tabular}{|c|c|c|c|c|c|}
\hline $\begin{array}{c}\text { S. } \\
\text { No. }\end{array}$ & $\begin{array}{c}\text { Variety/field } \\
\text { of guava }\end{array}$ & $\begin{array}{c}\text { No. of Galls } \\
\text { per 5 gm root }\end{array}$ & $\begin{array}{c}\text { No. of } \\
\text { egg masses } \\
\text { per 5 gm root }\end{array}$ & $\begin{array}{c}\text { No. of } \\
\text { eggs and larvae } \\
\text { per eggmass }\end{array}$ & $\begin{array}{c}\text { Nematode } \\
\text { population } \\
\text { per 200 cc soil }\end{array}$ \\
\hline 1. & Barafkhana & 74 & 58 & 162 & 934 \\
\hline 2. & Thai guava & 95 & 72 & 194 & 1376 \\
\hline 3. & Taiwan pink & 83 & 67 & 176 & 1162 \\
\hline & Average & $\mathbf{8 4 . 0 0}$ & $\mathbf{6 5 . 6 6}$ & $\mathbf{1 7 7 . 3 3}$ & $\mathbf{1 1 5 7 . 3 3}$ \\
\hline
\end{tabular}

Fig.1 Dead plant and bronzing leaves of guava due to Meloidogyne enterolobii

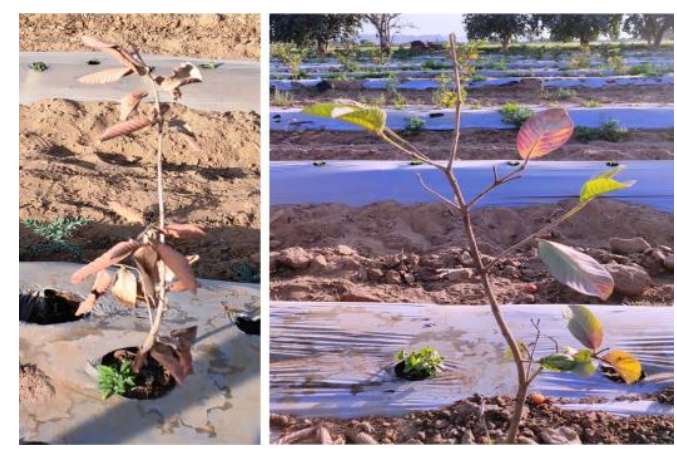

Fig.2 Galls on roots of guava produced by Meloidogyne enterolobii

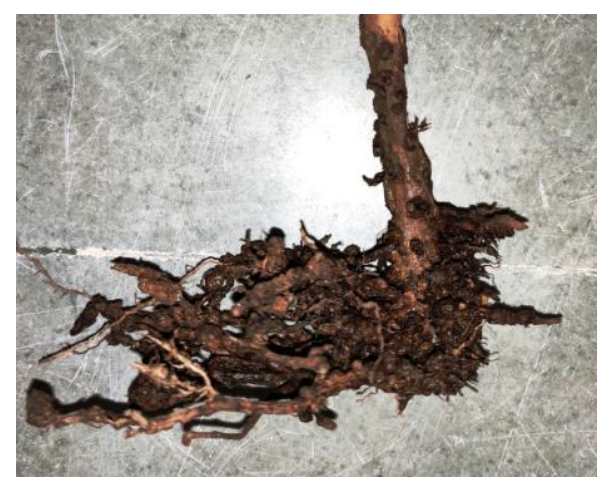

Fig.3 Perineal pattern of mature female of Meloidogyne enterolobii
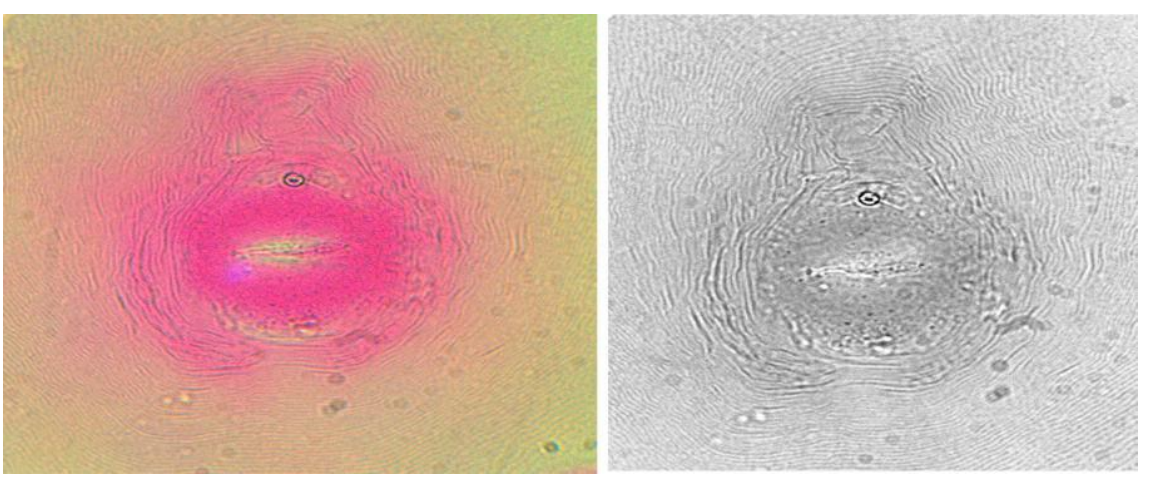
Fig.4 Meloidogyne enterolobii: (A) Second stage Juvenile; (B) J2 Head; (C) J2 Tail; (D) Mature Females; (E) Anterior portion of female; (F) Male; (G) Male head region; (H) Male tail region
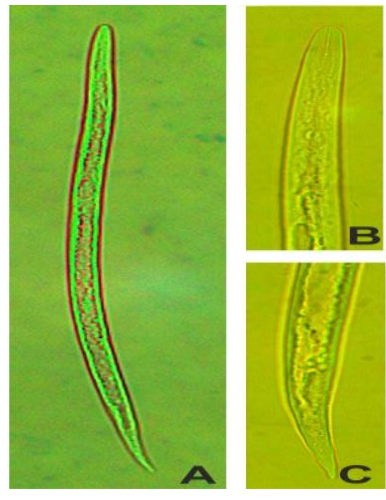

After the processing of samples, it was observed that the maximum 95 number of galls per $5 \mathrm{~g}$ roots found in Thai guava followed by 83 in Taiwan pink and 74 in Barafkhana. The highest number of egg masses per $5 \mathrm{~g}$ roots recorded in Thai guava (72) followed by Taiwan pink (67) and Barafkhana (58). The egg masses of this nematode contain maximum 194 eggs and larvae in Thai guava followed by 176 in Taiwan pink and 162 in Barafkhana. The final nematode population per $200 \mathrm{cc}$ soil were also recorded and it is found that the highest 1376 juveniles of Meloidogyne enterolobii observed in Thai guava followed by 1162 juveniles in Taiwan pink and 934 juveniles in Barafkhana varieties of guava and shown in table-5.

The results of morphological studies and parameters were similar to the Meloidogyne enterolobii. The characters of the species were similar to the original description of Meloidogyne enterolobii given by (Yang and Eisenback, 1983). (Rammah and Hirschmann, 1988) was first reported $M$. mayaguensison eggplants (Solanum melongena L.) in Puerto Rico and described the morphological characters of this nematode. (Suresh et al., 2019) also recorded the characterization and occurring of $M$. enterolobii in Tamil Nadu state of India.
The M. enterolobii was first reported in 2004 in the commercial orchards of guava at Limoeiro do Norte County (Torres et al., 2005). In the investigation of (Ansari and Khan, 2012) clearly indicated the association of root knot nematode, M. enterolobii with guava was highly pathogenic in nature. Similarly work also were recorded by some researchers and it was found that $M$. enterolobii infecting guava orchards in the various locations of different states worldwide such as Pernambuco and Bahia (Carneiro et al., 2001), Rio de Janeiro (Lima et al., 2003), Ceará (Torres et al., 2005), São Paulo (Almeida et al.,2006), Paraná (Carneiro et al., 2006), Piauí (Silva et al., 2006) and Espírito Santo (Lima et al., 2007).The host range of this nematode including vegetables, tomato, pepper, watermelon (Yang and Eisenback, 1983; Rammah and Hirschmann, 1988), guava (Gomes et al., 2012), ornamental plants (Brito et al., 2010) and weeds (Rich et al., 2009) are reported by many workers.

In India, it was first reported from guava orchards of Ayakudi villages of Dindigul district of Tamil Nadu by Poornima et al., (2016). Kumar and Rawat (2018) also recorded that $M$. enterolobii infecting guava in Uttarakhand state. (Kumar and Poornima, 2019) carried out a survey in major guava growing area of Tamil Nadu and found that 
M. enterolobii infected guava orchards in each district.

\section{Acknowledgement}

Authors are highly thankful to the Honorable Vice Chancellor and Director Extension Education of Agriculture University, Jodhpur (Rajasthan-India), Dean College of Agriculture, Nagaur and Staff Krishi Vigyan Kendra, Sirohi (Rajasthan-India) for providing necessary facilities, critical suggestions and co-operation for this work.

\section{Competing interests}

The authors declare they have no conflict of interest.

\section{References}

Almeida, E.J., Soares, P.L.M., Santos, J.M.and Martins, A.B.G. 2006.Estudo da resistência de araçás (Psidium spp.) (Mirtaceae) a Meloidogyne mayaguensis em casa de vegetação. Nematologia Brasileira, 30:118119.

Anonymous 2018-19a. Horticultural Statistics at a Glance 2018-19. Directorate of Economics and Statistics, Department of Agriculture and Cooperation, Ministry of Agriculture, Government of India, New Delhi.

Anonymous 2018-19b. Rajasthan Horticultural Statistics at a Glance 2018-19. Commissionerate of Agriculture, Department of Horticulture, Ministry of Agriculture, Government of Rajasthan, Jaipur-India.

Ansari, R.A.and Khan, T.A. 2012. Parasitic association of root-knot nematode, Meloidogyne incognita on guava. e-Journal of Science and Technology (e-JST), 5:6567.

Bohra, P. 2008. Quantitative and qualitative studies on plant and soil nematodes associated with crops of economic importance in Rajasthan. Records of the zoological Survey of India occasional paper no. 278:1-80.
Brito, J.A., Kaur, R., Cetintas, R., Stanley, J.D., Mendes, M.L., Powers, T.O. and Dickson, D.W. 2010.Meloidogyne spp. infecting ornamental plants in Florida. Nematropica, 40:87-103

Carneiro, R.G., Mônaco, A.P.A., Moritz, M.P., Nakamura, K.C.and Scherer, A. 2006.Identificação de Meloidogyne mayaguensis emgoiabeira e emplantasinvasoras, em solo argiloso, no Estado do Paraná. Nematologia Brasileira, 30:293-298.

Carneiro, R.M.D.G., Moreira, W.A., Almeida, R.M.A. and Gomes, A.C.M.M. 2001.Primeiroregistro de Meloidogyne mayaguensis emgoiabeira no Brazil. Nematologia Brasileira, 25:223-228.

Chitwood, B.G. 1949. "Root-knot nematodes" -I, A revision of the genus Meloidogyne Goeldi, 1887. Proceeding of Helminthological Society of Washington, 16:90-104.

Christie, J.R. and Perry, V.G. 1951. Removing nematodes from soil. Proceeding of Helminthological Society of Washington, 18:106-108.

Cobb, N.A. 1918. Estimating the nematode population of soil. U.S. Dept. Agr. Bur. Plant. Ind. Agr. Tech. Cir., 1:1-48.

Gomes, V.M., Souza, R.M., Midorikawa, G., Miller, R.and Almeida, A.M. 2012. Guava decline: Evidence of nationwide incidence in Brazil. Nematropica, 42:153-162.

Kumar, N.A. and Poornima, K. 2019. Occurrence and distribution of root knot nematode, Meloidogyne enterolobii in guava (Psidium guajava L.) in Tamil Nadu. Journal of Pharmacognosy and Phytochemistry, 8(2):1922-1924.

Kumar, S. and Rawat, S. 2018. First Report on the Root-Knot Nematode Meloidogyne enterolobii (Yang and Eisenback, 1988) Infecting Guava (Psidium guajava) in Udham Singh Nagar of Uttarakhand, India. Int. J. Curr. Microbiol. App. Sci.,7(04):1720-1724.

Lima, I.M., Dolinski, C.M. and Souza, R.M. 2003.Dispersão de Meloidogyne mayaguensis emgoiabais de São João da Barra (RJ) e relato de novo shospe deirosdentre plantasinvasoras e cultivadas. 
NematologiaBrasileira, 27:257-258.

Lima, I.M., Martins, M.V.V, Serrano, L.A.L.and Carneiro, R.M.D.G. 2007.Ocorrência de Meloidogyne mayaguensis emgoiabeira cv. „Paluma"e no estado do Espírito Santo Resumo. XXVIICongresso Brasileiro de Nematologia, Goiânia, GO, Brasil. pp 9697.

McBeth, C.W., Taylor, A.L. and Smith, A.L. 1941. Note on staining nematodes in root tissues. Proceeding of Helminthological Society of Washington, 8:26.

Moens, M., Perry, R.N. and Starr, J.L. 2009.Meloidogyne species - a diverse group of novel and important plant parasites. In: Perry RN, Moens M, Starr JL (Ed) Root-knot nematodes. Wallingford, UK, CAB International, pp. 1- 17.

Poornima, K., Suresh, P., Kalaiarsan, P., Subramanian, S. and Ramaraju, K. 2016. Root Knot Nematode, Meloidogyne enterolobii in Guava (Psidium guajava L.)A New Record from India. Madras Agriculture Journal, 103(10-12):359-365.

Rammah, A. and Hirschmann, $\mathrm{H}$. 1988.Meloidogyne mayaguensis $\mathrm{n}$. $\mathrm{sp}$. (Meloidogynidae), a root-knot nematode from Puerto Rico. Journal of Nematology, 20:58-69.

Rich, J.R., Brito, J.A., Kaur, R., Ferrell, J.A. 2009. Weed species as hosts of Meloidogyne: a review. Nematropica, 39:157-185.
Silva, G.S., Sobrinho, A.C., Pereira, A.L. and Santos, J.M. 2006.Ocorrência de Meloidogyne mayaguensis emgoiabeira no Estado do Piauí. Nematologia Brasileira, 30:307-309.

Suresh, P., Poornima, K., Kalaiarasan, P., Nakkeeran, S.and Vijayakumar, R.M. 2019. Characterization of Guava Root Knot Nematode, Meloidogyne enterolobii Occurring in Tamil Nadu. Int. J. Curr. Microbiol. App. Sci.,8(09):1987-1998.

Taylor, D.P. and Netscher, C. 1974. An improved technique of preparing perineal patterns of Meloidogyne spp. Nematologica, 20(2):268-269.

Thomas, L., Anitha, T., Lasyaja, A.B., Suganya, M., Gayathri, P.and Chithra, S. 2017. Biochemical and mineral analysis of the undervalued leaves - Psidium guajava. International Journal of Advanced Science and Research, 2(3):16-21.

Torres, G.R.C., Junior, A.R.S., Rehn, V.N.C., Pedrosa, E.M.R. and Moura, R.M. 2005. Occurrence of Meloidogyne mayaguensis on guava state of ceara. Nematologia Brasileira, 29(1): 105-107.

Yang, B. and Eisenback, J.D. 1983.Meloidogyne enterolobii $\mathrm{n}$. sp. (Meloidogynidae), a rootknot nematode parasitizing pacaraearpod tree in China. Journal of Nematology, 15:381-393.

\section{How to cite this article:}

Bhati, S. S. and Aabha Parashar. 2020. First Report and Morphological Description of Meloidogyne enterolobii Infecting Guava (Psidium guajava L.) in Transitional Plain of Luni Basin of Rajasthan. Int.J.Curr.Microbiol.App.Sci. 9(09): 2267-2274. doi: https://doi.org/10.20546/ijcmas.2020.909.282 